\title{
MOÇO EM ESTADO DE SÍTIO: RUPTURA E EXPERIMENTAÇÃO EM TEMPOS DE DITADURA
}

\author{
Luiz Paixão Lima BORGES*
}

\begin{abstract}
RESUMO: O presente artigo pretende apresentar alguns aspectos estéticos e dramatúrgicos da peça Moço em estado de sítio, de Oduvaldo Vianna Filho. A peça representa um salto qualitativo na produção dramatúrgica de um autor que sempre se debruçou sobre as contradições de nossa sociedade, tentando entendê-las, e a elas respondeu com uma obra consciente e empenhada na luta pela transformação social. Ao confrontar seus personagens com a realidade objetiva, demonstra que sua vinculação com as forças materiais condiciona dialeticamente seu desenvolvimento humano. As formas dramatúrgicas revelam tais condições, numa relação metonímica, visando a desvendar as contradições sociais e, com isso, revelar o caráter do personagem em seu processo de formação e atuação política. A peça inaugura um ciclo (Moço em estado de sítio, Mão na luva, Papa Highirte e Rasga coração) que têm no flashback sua técnica de composição e aprofundamento da utilização das formas do realismo psicológico e realismo dialético.
\end{abstract}

PALAVRAS-CHAVE: Dramaturgia brasileira. Teatro engajado. Realismo psicológico. Realismo dialético. Oduvaldo Vianna Filho.

\section{A condição do artista}

O artista não está alijado do processo de luta que cada momento histórico trava dentro de si mesmo. Embora a realidade se manifeste na obra de arte de forma consciente ou mesmo à margem da consciência do seu autor, consideramos

\footnotetext{
UFMG - Universidade Federal de Minas Gerais. Faculdade de Letras. Programa de Pós-Graduação em Estudos Literários. Belo Horizonte - MG - Brasil. 31270-901 - luizpaixaoteatro@gmail.com.
} 
que a visão de mundo, a ideologia do criador, pode amplificar as possibilidades de representação da realidade histórica na construção ficcional. Nesse sentido, entendemos que cabe ao escritor engajado ${ }^{1}$ perceber, compreender e configurar literariamente essa realidade, utilizando os recursos formais que se encontram à sua disposição, e que são, eles mesmos, condicionados pela realidade objetiva e subjetiva.

Como afirma Lukács (2010, p. 178), “toda estrutura poética é profundamente determinada, exatamente nos critérios de composição que a inspiram, por um dado modo de conceber o mundo". A concepção de mundo está intimamente vinculada ao contexto histórico, e sua variação ideológica responde à própria dinâmica do movimento da história, com o qual estabelece uma relação dialética. As ideologias se batem no esforço de se colocarem hegemonicamente uma sobre a outra: a luta entre suas contradições e o consequente acúmulo de forças promovem saltos qualitativos, que visam a compreender a realidade sob determinada concepção do mundo e criar respostas alternativas a cada um desses momentos.

[...] o escritor precisa ter uma concepção do mundo sólida e profunda; precisa ver o mundo em seu caráter contraditório para ser capaz de selecionar como protagonista um ser humano em cujo destino se cruzem os contrários. As concepções de mundo próprias dos grandes escritores se manifestam no plano da concepção épica. Na verdade, quanto mais uma concepção de mundo é profunda, diferenciada, alimentada por experiências concretas, tanto mais variada e multifacetada pode se tornar a sua expressão compositiva. [...] não há composição sem concepção de mundo. (LUKÁCS, 2010, p. 179).

O teatro de Oduvaldo Vianna Filho - Vianninha - se caracteriza por uma profunda tentativa de compreender e apresentar, no âmbito da literatura dramática, o homem brasileiro em confronto com suas necessidades e suas possibilidades. Uma dramaturgia carregada de significados sociais e forjada na procura de uma linguagem que pretende se aproximar à do homem comum, que estava bastante distante de nossa realidade teatral, profundamente influenciada que era pelo teatro europeu. Somente no final dos anos cinquenta do século passado o teatro brasileiro encontra as condições necessárias para criar e desenvolver uma dramaturgia empenhada numa discussão que tenha como objeto o debate franco sobre as questões mais pungentes de nossa sociedade. Em Vianninha, deparamo-nos com uma obra que tem no nacional e no popular dois de seus objetivos fundamentais: o nacional enquanto

1 Utilizamos aqui o verbo engajar no sentido de "pôr-se a serviço de uma causa", como o define o Dicionário Aurélio (FERREIRA, 1986), e que Raymond Willians categoriza como "alinhamento" ou "compromisso" (WILLIAMS, 1979, p. 198). 
rigorosa reflexão sobre a realidade brasileira e suas contradições sociais mais profundas; e o popular enquanto realização de um teatro que, além de se identificar com o homem brasileiro, traga-o para a cena como protagonista de seus próprios conflitos, e a ele retorne, enquanto uma política de conscientização, através da arte e da cultura.

Arguto observador da realidade e dotado de uma percepção privilegiada, de uma apurada consciência marxista, Vianninha foi um autor que se debruçou sobre as contradições de nossa sociedade, e a elas respondeu com uma obra consciente e empenhada na luta pela transformação social. Acompanhou o movimento histórico e político do país, participando destacadamente dos principais movimentos culturais nos anos de 1950 e 1960, adequando sua obra, tanto em seus aspectos formais quanto conteudísticos, à reflexão crítica de cada momento.

Vianninha encontrou no pensamento brechtiano os elementos necessários para uma escrita que, nos parâmetros do realismo dialético, apresente a realidade como passível de mudança. Brecht (1978), que entendia o teatro como um poderoso agente de transformação social, buscou novos elementos que contribuiriam para o melhor entendimento das relações sociais a que os homens estão subordinados. Para se entender o mundo como passível de modificação, é preciso compreender o homem como agente transformador e, ao mesmo tempo, transformável. Compreender a dinâmica do movimento e suas leis, regidas pela dialética; compreender que o movimento é absoluto e o repouso relativo; compreender que da observação nasce o espanto, do espanto surge a compreensão do observado. Brecht (1978) rompeu com a chamada forma dramática e formulou um novo e revolucionário pensamento para o teatro, o realismo épico-dialético, pois acreditava que

[...] só poderemos descrever o mundo atual para o homem atual, na medida em que o descrevermos como mundo passível de modificação. Para o homem atual, $\mathrm{o}$ valor das perguntas reside nas respostas. O homem de hoje interessa-se por situações e por ocorrências que possa enfrentar ativamente. (BRECHT, 1978, p. 6).

Por outro lado, consciente de que as relações sociais condicionam o comportamento humano, Vianninha investe no realismo psicológico como forma de compreensão do que se estabelece entre as motivações interiores e a práxis diária de seus personagens, acentuando como isso as suas contradições mais profundas.

A utilização de dois modelos de escrita dramatúrgica - realismo psicológico e realismo épico-dialético -, como operadores estéticos da peça Moço em estado de sítio, ao contrapor tempos e espaços diversos possibilitam uma realização estética em que forma e conteúdo experimentam uma complexa relação dialética, 


\section{Luiz Paixão Lima Borges}

mesmo que consideremos a primazia do conteúdo, uma vez que a determinação estética se efetiva a partir de sua organização. O dramático e o épico se completam e se explicam: os acontecimentos ganham forma e se traduzem dramaticamente; o comportamento do personagem central é confrontado, colocando-o em permanente estado de conflito e contradição.

Ao apresentar seus personagens em choque constante com a realidade social, Vianna demonstra que essa vinculação com as forças materiais condiciona dialeticamente seu desenvolvimento humano e sua consciência, reafirmando na prática dramatúrgica, a teoria marxista que ensina: "O modo de produção da vida material condiciona o processo da vida social, política e intelectual de maneira geral. Não é a consciência dos homens que determina o seu ser, mas ao contrário, seu ser social determina sua consciência." (MARX; ENGELS, 1979, p. 13).

As formas dramatúrgicas revelam tais condições, numa relação metonímica, visando a desvendar as contradições sociais e, com isso, revelar o caráter do personagem em seu processo de formação e atuação política. O aprimoramento de sua consciência ou a manifestação de sua alienação se realizam no momento em que se confronta com a realidade e, dela, retira matéria para a construção e afirmação de seus compromissos com a transformação social, política e econômica do país, visando a construção de uma etapa superior do desenvolvimento humano, bem como, em sua contraparte dialética, assumir o jogo determinado pelo sistema e a ele se entregar.

\section{Por um teatro empenhado}

A opção por realizar uma arte engajada vincula-se à percepção de que a realidade é passível de ser modificada, e cabe ao homem, e somente a ele, essa tarefa. No entanto, para que o homem a execute, é preciso que ele compreenda determinados mecanismos reguladores da ação coletiva e rompa com essa estrutura; é preciso que saiba que a transformação só se dá, efetivamente, com o deslocamento do poder de determinadas mãos para outras. A arte engajada tem como compromisso primeiro sensibilizar e despertar o homem para uma tomada de posição, uma vez que "a avaliação [do público] resulta da percepção consciente da obra de arte e dos sentimentos suscitados por esta" (OVSIÁNNIKOV, 1982, p, 154).

A resistência, forjada por um preconceito ideológico, que se criou em relação à arte engajada ou arte política, ou qualquer denominação que se dê a uma arte voltada para a defesa dos interesses dos trabalhadores, contrapondo-se, portanto, aos interesses da burguesia, favoreceu ao longo dos anos, particularmente, durante guerra fria - mas, também, depois dela, uma vez que "a retórica do mercado pós- 
guerra fria chega a ser mais anticomunista que a dos velhos tempos" (JAMESON, 1999, p. 13) - a ideia perversa de que a arte para apresentar qualidades literárias precisa afastar-se das questões de classe. Essa postura considera a arte política como arte menor; arte engajada é sempre arremedo, pois traz a marca do radicalismo e fanatismo político. No entanto, não existe arte que não seja política: "não existe qualquer obra de arte que seja inteiramente livre de conteúdo ideológico" (PLEKHANOV apud EAGLETON, 2011, p. 37).

Julgamos correto afirmar que a arte, seja ela proletária, seja ela burguesa, é engajada se defende os interesses de sua classe. Porém, não se diz que a arte burguesa é uma arte engajada. Tal epíteto se aplica, via de regra, apenas à arte que defende interesses da classe trabalhadora, de esquerda, socializante ou comunizante. Percebemos, portanto, uma clara manipulação ideológica por trás de tal postura, já que alimenta discriminação a uma literatura, ou qualquer outra forma de arte, que seja contra os interesses da classe dominante, no caso, a burguesia.

É preciso, antes, distinguir arte política e/ou engajada de arte de protesto, que, muitos, alguns por ignorância, outros por preconceito ou mesmo má-fé, insistem em confundir. Ainda que tenham uma mesma origem, as duas se diferenciam substancialmente em sua proposta estética e imediatismo da discussão proposta. A arte de protesto se caracteriza por responder a uma realidade determinada, de maneira crítica, denunciando os seus desvios e servindo a objetivos imediatos; nesses momentos específicos, ela se apresenta como uma poderosa arma de combate.

Em nosso país, particularmente nos anos de ditadura militar, a consciência dos artistas, intelectuais e escritores, não os traiu e os levou a um enfrentamento aguerrido contra as forças da repressão. A arte engajada e, em particular, o teatro com sua "vocação política" (DORT, 1977, p. 366), se colocou na frente de luta em favor das liberdades democráticas e melhores condições de vida para todos, não abriu mão de sua função social e engajou-se, correndo todos os riscos inerentes a uma luta política travada sob um regime de exceção.

O golpe de 1964 interrompeu um dos momentos mais ricos do nosso teatro, tanto em seu aspecto estético quanto em seu engajamento político, que compreendia a manifestação cênica como resultado de uma análise dialética da realidade, para, dando-lhe contornos artísticos, interferir na própria realidade e transformá-la. Como resposta e resistência ao golpe, nossos artistas se armaram com todas as suas forças e não se calaram diante ameaças constantes, como também não se calaram diversos segmentos da sociedade civil brasileira. Mas o teatro, por suas próprias características, foi a mais perseguida das artes.

A censura imposta pelo regime não foi apenas um mecanismo para impedir o acesso a determinadas obras de arte, consideradas ameaçadoras à ordem política e social: a censura foi substancialmente uma forma de impedir o artista de se 
comunicar com o seu público. Alguns dos nossos maiores nomes no teatro, na música, na literatura, mereceram atenção especial dos órgãos de repressão política. O seu pensamento sobre a realidade nacional, expressado nas peças, nas músicas, nos romances ou nos poemas, sofreram, além da vigilância cerrada, um processo de desarticulação promovido pelo impedimento de acesso às suas obras. É preciso reafirmar: a censura não atingiu apenas aquelas obras que foram proibidas por se considerar que representavam ameaça à segurança nacional e ao bom ordenamento do governo. A censura cindiu uma relação que não pode ser cindida: artista e público se distanciaram, pois, tiveram entre si, a tesoura do censor, sempre pronta a agir de acordo com o humor do seu manipulador, que detinha o poder absoluto para determinar o que podia ou não ser assistido, ouvido ou lido. O censor lançou mão desse poder sem critérios objetivos, muitas vezes seguindo apenas sua intuição de agente da repressão política.

$\mathrm{O}$ ato de censurar não permanece confinado em si mesmo, pois desencadeia todo um processo que, analisado à luz de uma consciência histórica, revela a formação de um estado de terror que, dentre tantas outras mazelas, promove o surgimento da autocensura, que não deve ser confundida com o processo de seleção das opções estéticas e temáticas que são próprias da criação artística. A autocensura desencadeia uma vigilância interna, motivada pelo temor e receio de uma reação externa, que impede ao artista a plena realização de sua obra. A dialética da autocensura é resultante do estado de terror implantado no Brasil, e que alguns artistas não souberam, não conseguiram ou não quiseram enfrentar. O prejuízo produzido pela autocensura jamais será mensurado ${ }^{2}$.

Ao longo de todo o período de obscurantismo e perseguições políticas, o teatro procurou formas, as mais diversas, para escapulir das garras do monstro da Censura Federal, e dizer, viva voz, o que pensava. Sem medo e sem se intimidar, trouxe para a cena discussões profundas e fundamentais, denúncias severas e críticas mordazes ao regime; lançou mão da metáfora e da parábola como seus principais recursos; às vezes, situando a ação dramática em outro tempo e espaço, ou mesmo criando situações absurdas, mostrou os desmandos cometidos pelo regime de força. O engajamento da dramaturgia se fez sentir de maneira clara e determinada.

\section{Um dramaturgo em estado de vigília}

Uma das características que marcam a trajetória artística de Vianninha é a sua capacidade de percepção dos momentos mais significativos das transformações históricas e as respostas que formula, estética e tematicamente, com o seu teatro,

\footnotetext{
2 Importante análise sobre a censura no teatro brasileiro, é a do crítico teatral Yan Michalsky (1979), em seu livro $O$ palco amordaçado, em que destaca ação da censura em obras que sequer foram escritas.
} 
a cada um desses novos momentos. Sua consciência artística, pari passu com sua consciência filosófica e política, fornece os instrumentos necessários para uma correta avaliação da realidade e adequação da prática artística ao momento histórico.

A adequação estética de sua obra responde a essas novas condições. Seu teatro é construído numa tentativa de compreender e atuar sobre a realidade, ainda que seja preciso abandonar métodos anteriores em favor de novas formas, que melhor possam responder a essas necessidades mais imediatas, para, num próximo momento, se necessário, voltar às antigas formas, agora já sob novas configurações, pois elas mesmas se transformaram. Ele não teme voltar para avançar. Sua dramaturgia opera saltos que revelam não apenas o acúmulo de experiências, como também radiografam sua trajetória enquanto artista atento ao movimento dialético da realidade e suas configurações estéticas.

A arte para mim é a transmissão de vivências, emoções, relações, representações e valores, que se incluem no aparelho imediato de conhecimento com que enfrentamos a realidade - desenvolvendo nossa capacidade de reagir sobre ela, nossa capacidade de inteligi-la e representá-la. Arte não é útil - porque não ligada à produção de bens materiais, não pode transmitir conceitos, nem pode definir e formar atitudes diante de fenômenos isolados - mas se inclui na cultura do homem, no seu aparato imediato com que representa os fenômenos sociais determinando suas aspirações, sentimentos, e criando as formas de ação com que representa e apreende esta realidade. A arte coordena e desenvolve as necessidades objetivas de representação do mundo que determinadas épocas e classe têm da realidade. (VIANNA FILHO, 1983a, p. 66-67).

Sua dramaturgia opera um extraordinário salto qualitativo na construção da peça Moço em estado de sítio: recuos e avanços no tempo, várias localizações espaciais, multiplicidade de ações e cenas que, simultaneamente, se confrontam e se completam, novo tratamento aplicado aos estados emocionais dos personagens que estão subordinados a um fluxo narrativo diferenciado e bem mais complexo. Tudo isso demonstra apuro técnico e domínio da carpintaria dramatúrgica. O resultado surpreende por sua dinâmica, manifestada na simultaneidade de ações, interrupções bruscas de cenas e a variedade de planos.

Seja na forma inovadora de sua dramaturgia, seja na investigação criteriosa do comportamento humano, somos confrontados com um dramaturgo consciente de seu ofício e maduro na condução de seus personagens e manipulação dos conflitos. Novas possibilidades dramáticas são incorporadas ao texto, sendo que o grande destaque está na valorização da luz como recurso definidor das relações temporais e espaciais, fundamentais no desenvolvimento e compreensão cênica da peça. 


\section{Luiz Paixão Lima Borges}

Sua expressividade surge como elemento estético primordial para a resolução dos problemas de mobilidade cênica que, na sua ausência, certamente, seriam um entrave cenográfico de difícil resolução.

O flashback tem sido um recurso amplamente utilizado no teatro, e tem como objetivo principal ampliar as relações tempo/espaço na dramaturgia, permitindo que a memória do personagem seja presentificada e personificada em cena. Do confronto dialético, que possibilita a presentificação do passado e, em contrapartida, promove a historicização do presente, o flashback atua tecnicamente na resolução ou aprofundamento dos conflitos dos personagens. Em termos de aplicação prática, ele pode se manifestar de duas formas distintas: surge como recurso epicizado, pois manipulado externamente pelo autor, como pode se manifestar através da memória do personagem, resgatando momentos de sua história que se refletirão em seu presente. As experiências de Oduvaldo Vianna Filho com esse recurso têm início em 1965, com a peça Moço em estado de sítio, seguida de Mão na luva (1966), Papa Highirte (1968), até atingir sua construção mais bem realizada em Rasga coração (1974).

As novas condições de produção impunham a urgência de repensar tudo, não apenas o repertório e a forma cepecista, que já não respondiam às necessidades imediatas e objetivas: superar a perplexidade inicial e manter viva a reflexão política e organização dos artistas e intelectuais comprometidos com a transformação social, em torno de um projeto dramatúrgico e cênico que extrapole sua função primeira de ser apenas um espetáculo à espera de um público. A posição do artista e do intelectual frente à realidade é posta em questão: o processo crítico e autocrítico, visando a encontrar outras possibilidades de formulação estética, depara-se agora com um contexto político que não fazia parte do seu repertório de atuação. Com o acesso às massas interditado, a classe média que havia apoiado o golpe se tornava, então, o alvo principal: a resistência à ditadura demandou uma discussão com outros setores da sociedade que se apresentavam dispostos a refletir sobre a realidade sóciopolítica do país, através das artes e da cultura.

Não se trata apenas de um redirecionamento mecanicista e automático do público, era preciso, antes, repensar as formas de expressão e a representação da classe média no interior da peça. Para retomar esse diálogo com os setores médios frequentadores de teatro, que fora interrompido durante o período de atuação do Centro Popular de Cultura (CPC), tornou-se urgente uma reorientação e reformulação de tudo o que havia sido feito anteriormente, tanto no âmbito dos temas a serem tratados, quanto na sua configuração estética.

Vianninha reorganiza o seu teatro investindo numa dramaturgia que se confronte com as novas condicionantes políticas e sociais; seu teatro busca oferecer formas e temas que se atualizam, sem perder o caráter de arte empenhada. $\mathrm{O}$ 
primeiro impasse frente a um estado militarizado é superado pela percepção da necessidade imediata de revisão dos modos de composição e sua capacidade de operacionalização de um novo projeto de teatro ${ }^{3}$.

Moço em estado de sítio retoma a perspectiva realista do Arena, porém, imprimindo nesta nova configuração o recurso da fragmentação que entra em choque com a linearidade característica do realismo. A reflexão política e estética operada na peça se aprofunda e apresenta os conflitos sob nova formulação: a análise do comportamento humano, depois daquela experimentada em Chapetuba Futebol Clube e que cedeu lugar a uma dramaturgia de circunstância cepecista, na qual o imediatismo político ofuscou a condição humana dos personagens, retorna agora encontrando um equilíbrio em que a construção realista psicológica plasma-se com elementos do realismo dialético. A utilização de duas estéticas aparentemente antagônicas não se traduz em contradição inconciliável. O realismo dialético, com todas as suas possibilidades estéticas, absorve o realismo psicológico e, com ele, cria uma terceira via de expressão, que contribui, de maneira decisiva para a compreensão da complexidade técnica da escrita e da encenação, assim como o entendimento da abordagem política e histórica.

Das relações entre os personagens - no confronto de suas possibilidades e necessidades - atinge-se a realidade objetiva, de modo a compreender suas múltiplas influências no próprio debate que se trava, permitindo que o sensível e o inteligível sejam apreendidos através do filtro da observação crítica, enquanto nas peças do CPC a realidade é apresentada de maneira direta, nos impondo por si mesmas; a crítica, uma vez que a mediação atende a objetivos políticos que pretendem atuar diretamente sobre o momento histórico.

A peça é reveladora do processo de transformação do próprio autor: ao discutir, no âmbito dramático, a função do artista e formas de atuação através do teatro de agitação a ser levado para o trabalhador, dramatiza um grupo de teatro que resgata $o$ modelo cepecista em suas propostas político-culturais; no entanto, sua configuração estética e concepção de seus personagens e seus conflitos, a caracterizam como uma peça destinada ao público de classe média. Melhor explicando: a peça ficcionaliza o processo de trabalho realizado no CPC - a utilização do teatro como transmissão de conhecimento e mobilizador de ações políticas através da conscientização das massas -, no entanto, a peça enquanto totalidade (escritura textual e espetacular), é dirigida à classe média, numa composição dramatúrgica cuja efetivação cênica só se torna possível numa casa que responda em seus recursos técnicos às necessidades de sua complexa estrutura.

\footnotetext{
3 A primeira experiência com essa nova proposta estética será observada no espetáculo Opinião (1964), escrito por Armando Costa, Paulo Pontes e Oduvaldo Vianna Filho, em que se coloca em cena três "personagens" que metonimicamente representavam o Brasil: o nordestino (João do Vale), o favelado carioca (Zé Kéti) e a representante da classe média (Nara Leão).
} 


\section{Luiz Paixão Lima Borges}

A peça recria, em seu próprio interior e em sua configuração formal, um momento de perplexidade e também de definição, experienciado por Vianninha e artistas de sua geração. Moço é o testemunho de uma crise, uma reflexão sobre a arte engajada e o impasse vivenciado pela tomada de poder pelos militares, onde se sente, de maneira significativa, a presença do autor, "quase um testamento existencial e político, por estranha que possa soar esta expressão aplicada a uma obra escrita aos 29 anos de idade" (MICHALSKI apud PATRIOTA, 2007, p. 176).

A peça retrata um período histórico vigorosamente rico em debates políticos e culturais, com uma destacada participação dos artistas e intelectuais nesse processo, e ficcionaliza essas contradições que remontam às crises vivenciadas por Vianninha no seu rompimento com o Teatro de Arena para formação do CPC, e, diante da decretação de sua ilegalidade, culminando com o enfrentamento da nova realidade imposta pela ditadura. Tais condições forneceram farto material para a configuração dramática de Moço.

O deslocamento temático, iniciado com o espetáculo Opinião, trazendo para o eixo dos conflitos personagens da classe média, espaço antes restrito ao proletariado, confirma a necessidade e a capacidade de mudança do autor. Repensar o fazer teatral significava não apenas uma questão estética, mas, sobretudo, encontrar uma linguagem que conseguisse atingir as exigências de um público frequentador de teatro, do qual estava afastado desde os anos do Arena. O dramaturgo compreendeu que o momento impunha a urgência de se buscar um outro fórum e um outro público disponível para travar uma discussão sobre os rumos do país, reagindo de maneira decisiva ao atual estado. A peça mimetiza as condições de crise vivenciadas pelos artistas: que teatro fazer nesses tempos em que a realidade não permite a completa realização de obras comprometidas com as questões sociais e políticas?

A discussão sobre a função do artista e do intelectual frente à conjuntura social abandona o plano teórico dos ensaios e artigos e entra, definitivamente, na obra dramatúrgica de Vianninha com Moço em estado de sítio. O debate travado em torno de uma arte empenhada, a procura incessante de uma participação política, a horizontalização da cultura, a atuação do teatro como agente formador de uma consciência crítica e mobilizador em torno de luta comum, se aproxima de maneira bastante perceptível às ações desenvolvidas no Arena e no CPC. No entanto, frente às novas condições de produção, busca-se uma síntese estética e política para esse novo enfrentamento que se apresenta para o intelectual e o artista brasileiros.

A consciência sitiada do intelectual e do criador identificado ao projeto políticocultural do CPC luta com suas próprias contradições, revê seu passado e as opções que fez. [...] O trabalho desenvolvido e os métodos empregados [pelo grupo de teatro] constituem uma óbvia alusão ao CPC. (BETTI, 1997, p. 204-205) 
O personagem central - Lúcio - assim como Vianninha, é um dramaturgo vinculado a um grupo de teatro que se propõe a um teatro de características populares, se aproximando do trabalhador e discutindo temas que julga relevantes para o crescimento de uma consciência política. Ainda que seja perceptível uma certa projeção do autor em seu personagem central, eles não se confundem: as dúvidas, conflitos e contradições pessoais de Vianninha são superadas pela ação objetiva, enquanto o personagem não consegue avançar em suas contradições, revelando uma incapacidade frente aos diversos impasses que the são apresentados: "a facilidade com que Lúcio transita de uma opção a outra revela a inconsistência de sua personalidade" (BETTI, 1997, p. 205). Embora existam vários pontos de contato entre criador e criatura, não se pode falar de uma peça autobiográfica, pois as diferenças se acentuam, ainda que as crises os aproxime. E a crise não é só do dramaturgo e do seu personagem, é a crise do teatro brasileiro que procura se reencontrar.

As divergências estéticas e políticas, surgidas no interior do grupo teatral, se apresentam em sua primeira cena: Lúcio defende uma atuação ampla, de maior proximidade com as massas trabalhadoras, num trabalho político de organização e mobilização, e não apenas de intervenção, desligada do contato íntimo e duradouro com o povo:

Lúcio - [...] Sem dinheiro, se mete em subúrbio, faz um espetáculo, não volta mais - se voltar é daqui um ano... a filosofia qual é, Suzana? [...]

Suzana - Você não vai nas reuniões, Lúcio. Fala lá. Você não ia trazer um plano pra levantar dinheiro?

Lúcio - Dinheiro para montar uma peça que prova que delatar é coisa feia? Isso, acho que tem gente dizendo desde que um tal de Judas... Judas, um palestino, lembra dele? (SILÊNCIO) Tem é que concentrar num bairro, só lá, Suzana. Fazer um clube, uma associação com o povo, não sei o que... mas não sair de lá... $\left(1^{\mathrm{a}} \cdot / 2\right)^{4}$.

A crise se efetiva motivada pelo choque de convicções divergentes sobre as formas de atuação política. Não há dúvida de que na fala de Lúcio identifica-se uma crítica aos métodos do CPC, que sofreu com a solução de continuidade em sua ação político-cultural. Num severo exercício de crítica e autocrítica, Vianninha parece estabelecer ligação entre os conflitos da peça e as ações cepecistas:

\footnotetext{
4 Todas as citações da peça Moço em estado de sítio serão indicadas no corpo do trabalho apenas pelos números de página entre parêntesis, na edição que consta das referências bibliográficas. A forma de numeração da cópia xerografada respeita a divisão das partes da peça: são três partes e, em cada página consta o número da parte e o número da página daquela parte, separados por uma barra.
} 
Qualquer trabalho de profundidade cultural, de horizontalização, de levar frutos culturais, exige em primeiro lugar um trabalho de continuidade, e essa continuidade para nós praticamente não existia. Eu acho que realizei espetáculos teatrais em praticamente todas as favelas do Rio de Janeiro. Mas eu devo ter realizado um ou dois em cada uma. Isso significa uma total descontinuidade. Realmente não tinha nenhum significado. Nós trabalhávamos em sindicatos, mas com condições de trabalho realmente utópicas. Era quase que o prazer da existência dessas condições e dessa atmosfera, e a dedicação, a capacidade de nos dedicarmos a esse trabalho, isso era quase que mais importante que os resultados concretos, que os frutos reais. Era, vamos dizer, a paixão por uma atmosfera. A paixão pelo encontro do intelectual com o povo, que realmente para nós era incandescente e ao mesmo tempo muito romântico, informou muito mais a nós do que aos trabalhadores com que nós entravamos em contato. Eles continuavam com seus problemas salariais, de organização, de sindicato, de lutas. (VIANNA FILHO, 1983b, p. 175) . $^{5}$

Por outro lado, é bastante significativo o confronto de ideias sobre a ação do teatro e, particularmente, sobre o processo de discussão do grupo, referente à peça de Lúcio, que, inevitavelmente, nos remete aos embates travados no Seminário de Dramaturgia do Arena em toda sua aspereza crítica e autocrítica, nos quais, não raras vezes chegou-se a agressões pessoais.

ENTRAM PESSOAS DO GRUPO E SENTAM. A LUZ MUDOU. SUZANA SENTA-SE AO LADO DE BAHIA. LÚCIO, NERVOSO, LÊ SUA PEÇA.

Lúcio - [Lendo a peça para o grupo] EMBAIXADOR - É uma bela medida, Governador. Mas se V. Excia. pedir ajuda dos russos, perderá a metade do apoio que tem dos comerciantes, dos homens de indústria. Metade, eu estou sendo otimista, otimista, Excelência? O Governador fica em silêncio. O Embaixador sorri. Levanta. Faz uma reverência. Sai. O Governador imóvel. Fim do $3^{\circ}$. Ato. (SILÊNCIO)

Um - Eu quero começar. Achei a peça muito importante. Parabéns ao companheiro. Dramaticamente talvez haja algum senão mas o sentido... antiimperialista me pareceu justo. É uma denúncia. Acho que ela...

Bahia - Que denúncia? Denúncia de que?

5 Entrevista concedida por Vianninha a Ivo Cardoso, em fevereiro de 74, cinco meses antes de sua morte, acontecida em julho do mesmo ano. É importante ressaltar que Vianninha foi, talvez, aquele que melhor construiu uma autocrítica em relação ao Arena e ao CPC. Seus escritos e suas duas últimas entrevistas publicadas o demonstram de maneira bastante clara. 
Vozes - Deixa ele falar, Bahia! - Espera a vez, Bahia.

Um - Denúncia da política do big stick, denúncia...

Bahia - Pra mim ele denuncia que política é uma coisa simples como água e que nós somos uma multidão de imbecis!

Vozes - Absolutamente! - Deixa ele falar! - Um de cada vez, um de cada...

Suzana - A burguesia vacilante está lá, o medo está lá, isso é simples?

Lúcio - O povo tem consciência mas não tem força, isso que eu...

Dois - Se ele tem consciência, ele tem força, companheiro...

Vozes - Não! - Quem disse isso? Quem? - A peça é simplista, meu velho...

Lúcio - Simples é essa crítica, não aceito assim, não aceito.

Dois - O que eu quero dizer é que a peça não mostra os erros do povo. Intenção em política não é nada. Em política, errou, pagou na hora.

Vozes - Mas é outra peça! - Assim não é possível! - A peça é didática! É simples, mas não é simplista...

Bahia - Política não é tragédia, não. Tragédia nem os gregos escreveram. O negócio é errou ou acertou. Essa revolução da peça entrou pelo cano porque eles erraram e o autor não sabe disso.

Lúcio - Eles erraram, pensaram que tinham força demais.

Bahia - Isso você está dizendo agora, porque na peça não tem, não.

Vozes - Como não tem? - A peça é didática! - Não pode querer obra-prima!

Suzana - A peça tem erros, sim. A peça do Bahia não tem erros? Só o Bahia acerta nessa praça? Isso não é maneira de tratar um trabalho de um companheiro. A peça é boa.

Bahia - Não é boa não. Que tem uma peça não ser boa? (LÚCIO FALA. AS LUZES EM VOLTA DOS OUTROS COMEÇAM A APAGAR)

Lúcio - Boa é a sua peça sobre delação, não é? Minha peça é sobre uma revolução, pomba. Ou só pode se escrever sobre delação aqui? Algumas colocações eu aceito, mas invalidar tudo? Não aceito. (2\%/4-6).

Para Vianninha, as contradições que enfrentava no Arena já estavam superadas: não encarava mais como problema fazer teatro para a classe média discutindo os problemas dela, uma vez que nela poderia encontrar aliados para efetivar a luta.

O processo cultural, o aprofundamento cultural, tem de ser feito diante das forças que absorvem cultura na sociedade brasileira. Eu não posso inventar outros 


\section{Luiz Paixão Lima Borges}

componentes de absorção de cultura. O processo cultural deve ser feito de quem vive e absorve esse troço. (VIANNA FILHO, 1983b, p. 175-176).

A luta pela democracia, que está diretamente vinculada à luta pela liberdade de expressão e melhores condições de vida para a população, encontra no teatro um grande aliado. A repercussão positiva do espetáculo Opinião confirma a Vianninha a correção do caminho escolhido. A aproximação com "a classe média mais típica, aquela de Copacabana contemporânea" (ANTÔNIO MERCADO apud GUIMARÃES, 1984, p. 65-66) promove a identificação do público com os personagens e temas apresentados:

[...] as contradições, as angústias, os vagos anseios, as lutas, as frustrações dessa classe constituem acima de tudo mais a matéria prima que o autor molda e na qual incrusta a discussão dos temas que lhe parecem fundamentais, tanto do ponto de vista ideológico e existência como à luz da conjuntura sócio-política brasileira. Vianninha soube detectar com maestria os conflitos internos e externos desse extrato social. (ANTÔNIO MERCADO apud GUIMARÃES, 1984, p. 65-66).

A classe média, que vivia a contradição de ter apoiado o golpe e começava a sentir na carne a primeiras consequências de seu ato, é o alvo a ser confrontado com a disposição e atuação política dos personagens que, através do teatro pretendem a transformação social. Como seu representante, o personagem central traz no seu comportamento as mesmas fragilidades e inconsistência ideológica típicos de uma classe que, no processo histórico, tem se mostrado vacilante e oportunista ${ }^{6}$. A consciência política de Lúcio, demonstrada em sua participação no grupo de teatro, choca-se de frente com seus desvios éticos e morais, que irão ser apresentados ao longo da peça. O personagem não consegue administrar suas contradições, permitindo que tais desvios se manifestem de maneira a obliterar sua atuação política.

Através do debate em torno das contradições da classe média, é possível abordar, dentro dos limites impostos pela censura que começava a mostrar sua tesoura, a realidade em suas diversas manifestações. A discussão política e econômica repercute no comportamento dos personagens, para retornar, agora reconfigurada, como crítica implícita ao sistema e ao próprio regime. O que se vê no palco, "mesmo que se tenha que selecionar mais cuidadosamente a minha temática [...] para enquadrá-la nos padrões permitidos" (VIANNA FILHO apud

6 Outras peças de Vianninha irão discutir as relações políticas e ideológicas da classe média, dentre elas, devemos destacar: Mão na luva (1966), Corpo a corpo (1970), Em família (1970), Alegro desbum (1972). O tema da classe média será imortalizado no seriado de televisão A grande família (1973), escrito em parceria com Armando Costa. 
GUIMARÃES, 1984, p. 57), é o retrato de um país que se encontra num impasse em que a moral e a ética estão corrompidos, um país do "salve-se quem puder", da lei do mais forte, da vantagem a qualquer custo, comportamento que em meados dos anos 70 viria a ser estigmatizado pela "lei de Gerson".

Lúcio é a representação de um momento histórico, de uma classe que não consegue se impor, pois encontra-se no eterno dilema de não aceitar ser proletário e não conseguir ser dominante, mas continua alimentando o sonho de ascensão social. No microcosmo dramático, nos deparamos com um sistema semelhante, pois as possibilidades não estão abertas a todos, e, para a satisfação de suas necessidades, é preciso se vender a ele e fazer o jogo imposto pela classe dominante. Lúcio não consegue se impor frente ao grupo de teatro com sua obra dramatúrgica e, para superar essa frustração, se vende ao sistema e trai os companheiros. Lúcio aceita o jogo e vai trabalhar numa revista que defende interesses do sistema: talvez se dê bem, talvez seja destruído pelo mesmo esquema que o absorveu e determinou as condições de convivência.

Para Vianninha, discutir a classe média e seus comportamentos contraditórios, foi a maneira de compreender um pouco mais o Brasil e sua realidade. Seu projeto se apoia na reconstrução de um teatro que continue afirmativo em seus propósitos fundamentais, embora as condições sejam as mais adversas, por isso mesmo a necessidade de outras formas e outros temas.

Para que o teatro possa atuar, possa divertir - possa reunir um mundo de sensações novas, originais, recém-reveladas - a condição política básica é a existência da democracia; a liberdade de expressão e de manifestação do pensamento. [...] Teatro participante é a paixão, a profunda paixão da descoberta do espírito humano contemporâneo. [...] A democracia foi destruída enquanto organização, mas não enquanto absoluta aspiração do povo e do artista brasileiro. A destruição dos valores democráticos custou também a destruição de vários mitos que enredavam a consciência social. (VIANNA FILHO, 1983c, p. 103-104)

\section{MOÇO EM ESTADO DE SÍTIO: RUPTURE AND EXPERIMENTATION IN TIMES OF DICTATORSHIP}

ABSTRACT: This article intends to present some aesthetic and dramaturgical aspects of the play Moço em estado de sítio, by Oduvaldo Vianna Filho. The play represents a qualitative leap in the dramaturgical production of an author who has always looked at the contradictions of our society, trying to understand them, and responding to them through a conscious and committed work in the struggle 
for social transformation. By confronting his characters with objective reality, he demonstrates that his attachment to material forces dialectically conditions his human development. The dramaturgic form reveals such conditions in a metonymic relation, in order to unravel the social contradictions and, through this, to display the nature of the character in its process of formation and political action. The play inaugurates a cycle (Moço em estado de sítio, Mão na luva, Papa Highirte and Rasga coração) that uses flashbacks as a composition technique in order to deepen the psychological and dialectical realism.

KEYWORDS: Brazilian dramaturgy. Engaged theater. Psychological realism. Dialectical realism. Oduvaldo Vianna Filho.

\section{REFERÊNCIAS}

BETTI, Maria Silvia. Oduvaldo Vianna Filho. São Paulo: Edusp, 1997.

BRECHT, Bertolt. Estudos sobre teatro. Trad. Fiama Pais Brandão. Rio de Janeiro: Nova Fronteira, 1978.

DORT, Bernard. O teatro e sua realidade. Trad. Fernando Peixoto. São Paulo: Perspectiva, 1977.

EAGLETON, Terry. Marxismo e crítica literária. Trad. Matheus Corrêa. São Paulo: Unesp, 2011.

FERREIRA, Aurélio Buarque de Hollanda. Novo dicionário da Língua Portuguesa. 2. ed. Rio de Janeiro: Nova Fronteira, 1986.

GUIMARÃES, Carmelinda. Um ato de resistência - o teatro de Oduvaldo Vianna Filho. São Paulo: MG Editores Associados Ltda, 1984.

JAMESON, Fredric. O método Brecht. Trad. Maria Silvia Betti. Revisão técnica Iná Camargo Costa. Petrópolis (RJ): Vozes, 1999.

LUKACS, György. Marxismo e teoria da literatura. 2. ed. Trad. Carlos Nelson Coutinho. São Paulo: Expressão Popular, 2010.

MARX, Karl; ENGELS, Friedrich. Sobre literatura e arte. Trad. Olinto Beckerman. São Paulo: Global, 1979.

MICHALSKI, Yan. Longa jornada estado de sítio adentro. In: PATRIOTA, Rosangela. A crítica de um teatro crítico. São Paulo: Perspectiva, 2007. 
Moço em estado de sítio: ruptura e experimentação em tempos de ditadura

. O palco amordaçado: 15 anos de censura teatral no Brasil. Rio de Janeiro: Avenir, 1979.

OVSIÁNNIKOV, M. F. et al. Fundamentos da estética marxista. Trad. Iu. Mélnikov. Moscou: Progresso, 1982.

PATRIOTA, Rosangela. A crítica de um teatro crítico. São Paulo: Perspectiva, 2007.

PEIXOTO, Fernando. (Seleção, organização e notas). Vianinha - teatro, televisão, política. São Paulo: Brasiliense, 1983.

VIANNA FILHO, Oduvaldo. Moço em estado de sítio. Cópia xerografada.

. O artista diante da realidade (um relatório). In: PEIXOTO, Fernando. (Seleção, organização e notas). Vianinha - teatro, televisão, política. São Paulo: Brasiliense, 1983a.

. Entrevista a Ivo Cardoso. In: PEIXOTO, Fernando. (Seleção, organização e notas). Vianinha - teatro, televisão, política. São Paulo: Brasiliense, 1983b.

. Perspectivas do teatro em 1965. In: PEIXOTO, Fernando. (Seleção, organização e notas). Vianinha - teatro, televisão, política. São Paulo: Brasiliense, 1983c.

WILLIAMS, Raymond. Marxismo e literatura. Trad. Waltensir Dutra. Rio de Janeiro: Zahar, 1979.

Recebido em 09/02/2018.

Aprovado em 18/04/2018. 
